\title{
Antiidiotypic Antibody Vaccine in Murine Schistosomiasis mansoni Comprising the Internal Image of Antigen
}

\author{
Thomas F. Kresina and G. Richard Olds \\ Department of Medicine, The Miriam Hospital and Brown University School of Medicine, Providence, Rhode Island 02906
}

\begin{abstract}
This study presents the characterization of an experimental immunotherapeutic approach for schistosomiasis utilizing antiidiotypic antibodies. Antiidiotype (31-3B6) was generated in rabbits using a protective murine monoclonal antibody $31-3 B 6$ which recognizes a 68,000-D molecular mass glycoprotein present in extracts of Schistosomiasis mansoni adult worm homogenetics. Immunization of mice with antiidiotype (31-3B6) before $S$. mansoni cercariae infection resulted in protection levels ranging from 16 to $41 \%$ depending on the route of administration of antiidiotypic antibody and the use of adjuvant. Levels of protection as high as $25 \%$ could be obtained with a single injection of antiidiotype (31-3B6) without the use of adjuvant. Animals noted to be resistant to infection with $S$. mansoni cercariae were also noted to exhibit a humoral immune response that bound components of $S$. mansoni adult worm homogenetics. This induced antiantigen immune response was shown to bind to the surface of $S$. mansoni schistosoma by indirect immunofluorescence. Further characterization of the induced antiantigen response showed that a portion (3-32\%) of the induced humoral immune response portrayed the binding specificities of the murine monoclonal antibody 31-3B6. The data indicate that antiidiotype antibodies generated utilizing defined monoclonal antibodies can act as surrogate antigens in the protection of infection in schistosomiasis.
\end{abstract}

\section{Introduction}

The immune response to a given antigen can be regulated through a series of complementary interactions involving idiotypic and antiidiotypic determinants (1). Numerous studies have shown that idiotype-antiidiotype interactions can result in either suppression or stimulation of an immune response (2-4). When antigen is presented to the immune system, immunoglobulin reactive to antigen is produced $\left(A b_{1}\right)$. These antibody molecules have unique structural components, termed idiotypes, which can stimulate a second cascade of antibodies $\left(\mathrm{Ab}_{2}\right)$ directed at these unique structures. These anti-antiantigen molecules are termed antiidiotypic antibodies. The regulation of immune responses by these molecules is based on the complementary structural relationship between idiotype and antiidiotype, particularly when the relevant idio-

Address reprint requests to Dr. Kresina, Program in Geographic Medicine, The Miriam Hospital, 164 Summit Avenue, Providence, RI 02906.

Received for publication 25 January 1988 and in revised form 16 September 1988.

\section{J. Clin. Invest.}

(C) The American Society for Clinical Investigation, Inc.

0021-9738/89/03/0912/09 \$2.00

Volume 83, March 1989, 912-920 type is in or near the antigen binding site. Specifically, antiidiotypic antibodies that are antigen binding site-related often portray the internal image of antigen (5-7). These internal image antiidiotypic antibodies stimulate the immune system in a similar fashion to antigen by mimicking its antigenic structure. In this capacity, antiidiotypic antibody, which portrays the internal image of antigen, can induce an immune response $\left(\mathrm{Ab}_{3}\right)$ that is anti-antigen. In effect, antiidiotypic antibodies $\left(A b_{2}\right)$ stimulate an $A b_{3}$ response that is serologically and functionally identical to the $A b_{1}$ response induced by antigen.

Application of these observations has resulted in antiidiotype antibody vaccine(s) against a variety of infectious pathogens and tumors in several species of experimental animals including primates (8-13). The initial report of an effective antiidiotype vaccine involved the induction of protective immunity against the protozoa, Trypansoma rhodesiense infection $(14,15)$. With other infectious diseases including Streptococcus pneumonia (16), Escherichia coli K13 infections (17), hepatitis B virus (18), Sendai virus (19), reovirus (20), and polio virus type III (21) the principle of idiotypic vaccination has been applied. In these studies varying levels of protective immunity were induced. In the present investigation an antiidiotypic antibody vaccine was developed against the multicellular helminth, Schistosoma mansoni and shown to induce protection against a primary challenge by infective cercariae using various vaccination protocols. Protection was noted even when the antiidiotypic antibody vaccine was given without adjuvant or after a single administration. When directly compared to purified antigen, equal or lower concentrations of antiidiotype induced equivalent in vivo protection. Analysis of the antischistosomal immune response, induced by the antiidiotype vaccine, indicated that vaccination resulted in an antibody response directed toward a defined antigen as well as the surface of schistosoma (the invasive larval form of the parasite). Taken together, these data indicate that antiidiotype vaccines in schistosomiasis induce effective protection to reinfection by acting as structural surrogates of protective antigens.

\section{Methods}

31-3B6 is an IgM monoclonal antibody produced from the fusion of splenocytes of a Balb/C mouse hyperimmunized with adult schistosome antigens (SWAP) with the Balb/C myeloma line $\mathrm{P}_{3} \mathrm{NS} 1$ (22). Supernatants from the resultant hybrid clones were screened for reactivity with SWAP by ELISA and binding to living schistosomula by indirect immunofluorescence and shown to be a candidate vaccine (22). Large quantities of monoclonal antibodies were produced in $\mathrm{Balb} / \mathrm{C}$ mice as ascites fluid.

For the present studies, 31-3B6 antibody was purified from ascites fluid by ammonium sulfate precipitation and molecular sieve chromatography using a CL6B column (Pharmacia Fine Chemicals, Piscataway, NJ). The IgM fraction was recovered and dialyzed extensively versus PBS, pH 7.6. Assessment of purity was performed by SDS electrophoresis and silver staining. 
Xenogeneic antiidiotypic antisera was generated in the following manner. $5 \mathrm{mg}$ of chromatographically purified 31-3B6 antibody was emulsified in complete Freund's adjuvant and injected subcutaneously into numerous spots on the back, axilla, and groin of three 3-5-kg New Zealand white rabbits.

Immunization was repeated 2 wk later with purified 31-3B6 antibody and incomplete Freund's adjuvant. All rabbits were then boosted with 31-3B6 antibody ( $5 \mathrm{mg} / \mathrm{rabbit}$ ) subcutaneously every other week for a total of eight doses. $1 \mathrm{wk}$ after the last immunization, animals were bled via an ear artery and serum was collected. Balb/C immunoglobulin was prepared from ascites fluid of pristane-treated mice by a $33 \%$ ammonium sulfate precipitation. All three rabbit sera produced a dense precipitation band with purified $31-3 \mathrm{~B} 6$ as well as purified $\mathrm{Balb} / \mathrm{C}$ immunoglobulin by Ouchterlony analysis.

Purified Balb/C immunoglobulin was covalently coupled to Sepharose. Mouse antiisotypic and antiallotypic antibodies present in these rabbit sera were then absorbed by chromatography. Reactivity for 31-3B6 antibody versus normal mouse IgM was determined by Ouchterlony analysis and subsequently by an assay for idiotype reactivity $(23,24)$ as described below. Only one rabbit produced an absorbed anti-sera that precipitated on Ouchterlony analysis as a dense band with 31-3B6 antibody but not with Balb/C immunoglobulin. This rabbit was repeatedly boosted and bled and various serum pools created. One pool of $200 \mathrm{~cm}^{3}$ of serum was absorbed, tested, and used for the experiments outlined.

Quantification of anti-id activity. Rabbit antiidiotype activity was quantified by an indirect method of precipitation as described previously $(23,24)$. In brief, purified $31-3 B 6$ was labeled with ${ }^{125}$ I using chloramine $\mathrm{T}(25) .10 \mathrm{ng}$ of this labeled ligand was then incubated with serial dilutions $(1: 10$ to $1: 20,480)$ of absorbed rabbit antisera. This reaction mixture also contains $10 \mu \mathrm{g}$ of normal Balb/C immunoglobulin to absorb any residual antibody activity directed toward isotypic or allotypic determinants. The mixture was incubated for $1 \mathrm{~h}$ at $37^{\circ} \mathrm{C}$ and immune complexes precipitation facilitated by the formation of a carrier precipitate comprised of absorbed goat antirabbit ovalbumin and goat antirabbit $\operatorname{IgG}(23,24)$. Data are presented as ${ }^{125} \mathrm{I}$-precipitable counts per minute binding 31-3B6 above background counts per minute, which ranged from 1 to $3 \%$ of total counts per minute.

Characterization of antiidiotype 31-3B6. A solid-phase radioimmune assay $(23,24)$ and ELISA were used to determine the characteristic binding patterns of rabbit anti-idiotype 31-3B6. ELISA was performed as described previously (22) utilizing absorbed rabbit antiidiotype 31-3B6 as the well coat. The solid-phase radioimmune assay used purified 31-3B6 antibody (kindly provided by Dr. Charles King, Case Western Reserve University, Cleveland, $\mathrm{OH}$ ) as the well coat. Inhibition of binding of the (31-3B6-antiidiotype) binding was determined for the following reagents: sera from mice administered antiidiotype 31-3B6 and shown to be protected from infection; purified 31-3B6 antigen ( $68 \mathrm{kD}$ glycoprotein kindly provided by Dr. Charles King) (22); and pooled sera from Fisher rats exposed to two infections with $S$. mansoni cercariae and portraying a 50-60\% level of protection rom reinfection (kindly provided by Dr. Paul Knopf, Brown University, Providence, RI). In this inhibition assays, binding levels of rabbit antiidiotype 31-3B6 were determined using ${ }^{125}$ I specifically purified goat antirabbit IgG (Cappel Laboratories, Cochranville, PA).

Isolation of the 68-kD antigen recognized by 31-3B6. A purified 68-kD glycoprotein antigen was purified by immunoaffinity column chromatography using a 31-3B6-coupled Sepharose column. The eluted material was suspended in PBS. Protein concentration was determined by the method of Lowry et al. (26). Optimal concentrations were used for protection comparative studies as previously determined (22).

Immunization protocols and infection. CF1 outbred mice (Charles River Breeding Laboratories, Wilmington, MA) were immunized with antiidiotypic antibody with or without complete Freund's adjuvant (CFA; Gibco Laboratories, Grand Island, NY). Unless otherwise indicated, $500 \mu \mathrm{g}$ of protein in $200 \mu \mathrm{l}$ was used. Adjuvant injections comprised a mixed 1:1 (vol/vol) tight emulsion. Nonadjuvant containing preparations were suspended in physiologic saline. Animals were injected with antiidiotypic antibody and CFA either intraperitoneally or subcutaneously, while nonadjuvant injections were made intradermally, subcutaneously, or intravenously via the tail vein.

$10 \mathrm{~d}$ after the last immunization, animals were bled retroorbitally and individual serum samples collected. 2-4 wk after the last immunization, animals were challenged transdermally with cercariae of a Puerto Rican strain of $S$. mansoni (27).

Resistance to infection was determined by either recovery of migrating larvae from the lungs (28) or recovery of adult worms from the mesenteric vasculature of infected mice (27). In the former assay, mice were anesthesized and infected with 500 cercariae. Animals were killed $7 \mathrm{~d}$ later, their lungs were removed, and the number of migrating larvae were enumerated microscopically (28). Adult worm recoveries were performed in animals infected with 100 cercariae 6 wk postinfection (27). Anesthesized mice have their portal systems perfused and the number of adult worms/mouse enumerated.

To determine percent protection the following formula was used: Worms recovered from control mice - Worms recovered from $\times 100$ experimental mice/Worms recovered from control mice. Statistical analysis of data was performed using the Student's $t$ test.

Antibody response of vaccinated animals. Serum from control animals or mice vaccinated with antiidiotypic antibody was examined for its ability to bind soluble worm antigens (SWAP) by ELISA as previously described (29). In brief, SWAP is produced from adult $S$. mansoni worms by emulsification with a tissue grinder and ultracentrifugation (30). SWAP is diluted in PBS, $\mathrm{pH} 7.2$, to a final concentration of $100 \mathrm{ng} / \mathrm{ml}$ and $100 \mu \mathrm{l} /$ well added to a 96-well flexible microtiter plate (Microtest III; Falcon Labware, Oxnard, CA). After overnight incubation, BSA (Sigma Chemical Co., St. Louis, MO) is used to block unused protein binding sites on the plate. Serum to be tested is diluted from $1 / 10$ to $1 / 100,000$ along with a normal mouse serum control. After incubation, the plate is vigorously washed and the binding of mouse immunoglobulin detected by a rabbit anti-mouse-alkaline phosphatase conjugate (New England Nuclear, Boston, MA). Binding of this second reagent is detected by adding $1 \mathrm{mg} / \mathrm{ml} p$-nitrophenyl phosphate to the washed plate and determining absorbance over time at $405 \mathrm{~nm}$.

Binding to living schistosomula was determined by indirect immunofluorescence. Schistosomula were prepared mechanically and used 4 h later (31). 50 schistosomula were incubated with $1 / 50$ and $1 / 100$ dilutions of mouse sera for $1 \mathrm{~h}$ at $37^{\circ} \mathrm{C}$ and then $1 \mathrm{~h}$ at $4^{\circ} \mathrm{C}$. Schistosomula were then washed four times with Hanks' balanced salt solution (K.C. Biologicals, Kankakee, IL) and antibody binding detected using a fluorescence (FITC) conjugated goat anti-mouse Ig (Cooper Biomedical, Malvern, PA) according to the method of Zodda and Phillips (32).

Competitive inhibition of binding of the antischistosomal immune response. Sera of vaccinated mice noted to contain both anti-SWAP antibody (by ELISA) and antischistosomula antibody (by fluorescence) were then analyzed further by two other methods to determine the specificity of the induced anti-worm antigen antibody $\left(\mathrm{Ab}_{3}\right)$ response. Initially, murine serum samples $\left(\mathrm{Ab}_{3}\right.$ containing serum) and control sera were analyzed for the presence of $\mathrm{IgG}$ antibodies which bound antigen (SWAP:) but could be inhibited from binding to antigen by monoclonal antibody 31-3B6. Therefore, this RIA determines the percentages of the $A b_{3}$ response that is sterically hindered from binding antigen (i.e., antibodies which bind to epitope(s) on SWAP which are also recognized by 31-3B6). In this assay, SWAP was solubilized and diluted and used to coat 96-well microtiter plates as described previously (29). After incubation, BSA was utilized to block the remaining reactive sites of the microtiter wells. 31-3B6 monoclonal IgM antibody was incubated overnight in the wells. After incubation, the wells were washed thoroughly and a nonsaturating dilution of murine sera, containing IgG ( $\mathrm{Ab}_{3}$ molecules), was incubated in the wells at room temperature for $1 \mathrm{~h}$ and then washed. Binding of IgG $\mathrm{Ab}_{3}$ molecules was detected by an absorbed isotype-specific rabbit anti-mouse IgG 
(Cooper Biomedical). Data are presented as percent inhibition of binding by 31-3B6 of $\mathrm{Ab}_{3}$ antibody binding to antigen.

A second assay performed to determine the specificity of induced $\mathrm{Ab}_{3}$ antibody in vaccinated mice utilized the purified $68-\mathrm{kD}$ antigen as a competitive inhibitor. The $68-\mathrm{kD}$ antigen, recognized by monoclonal antibody 31-3B6 was used to inhibit the binding of induced $A b_{3}$ to antigen (SWAP). Therefore, this RIA would substantiate the initial observation that $\mathrm{Ab}_{3}$ antibodies induced by vaccination with antiidiotypic antibody $\left(\mathrm{Ab}_{3}\right)$ could recognize a specific SWAP antigen related to the molecule used to induce the $A b_{3}$ population. In these studies increasing amounts of $68 \mathrm{kD}$ antigen $(10-5,000 \mathrm{ng})$ were preincubated with murine antisera at $37^{\circ} \mathrm{C}$ for $1 \mathrm{~h}$ before incubation in SWAPcoated polyvinyl microtiter plates. Binding was detected using a ${ }^{125} \mathrm{I}$ goat anti-mouse IgG. Data is presented as percent inhibition of binding to antigen by nanogram quantities of $68 \mathrm{kD}$ antigen.

\section{Results}

Antiidiotypic binding of rabbit serum. Serum from outbred rabbits hyperimmunized with monoclonal antibody 31-3B6 was absorbed by passage through normal mouse immunoglobulin coupled-Sepharose columns. Absorbed sera that was negative for binding to normal mouse immunoglobulin but which precipitated 31-3B6 antibody was then analyzed quantitatively for binding to radiolabeled ligand (31-3B6) in an assay for idiotype. As shown in Fig. 1 antiidiotype antibody containing absorbed rabbit sera bound $>80 \%$ of radiolabeled $31-3 \mathrm{~B} 6$ monoclonal antibody in the presence of a two-log excess of normal mouse immunoglobulin. These data indicate that the absorbed rabbit sera recognized epitopes specific to variable regions found on monoclonal antibody 31-3B6. Background binding levels in this assay, using either BSA or an irrelevant monoclonal antibody, were $<5 \%$ of the labeled ligand. Analysis of the binding curve also demonstrated that $500 \mu \mathrm{g}$ of ab-

\section{BINDING CURVE OF RABBIT SERUM HYPERIMMUNIZED WITH 31-3B6}

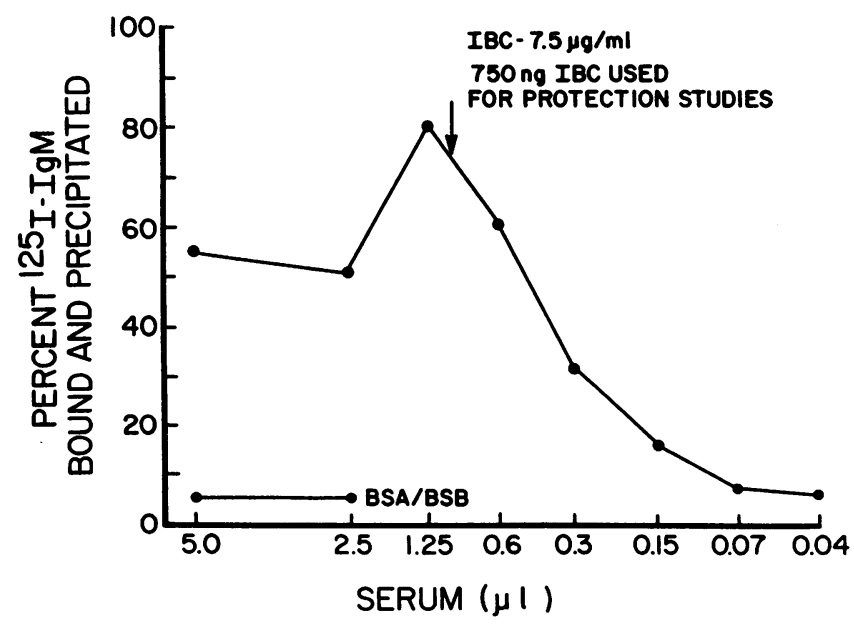

Figure 1. Binding curve of rabbit serum derived from animals hyperimmunized with $100 \mu \mathrm{g}$ of soluble egg antigen preparation emulsified in complete Freund's adjuvant. Data reflect binding of serial dilutions of rabbit serum determined in the assay for idiotype described in Methods. Idiotype binding capacity is determined by the pentultimate value of the linear portion of the binding curve as described previously $(23,24)$. sorbed rabbit serum contained 750 ng idiotype binding capacity (IBC) of activity.

Antiidiotypic antibody as a vaccine in S. mansoni. In initial studies, anti-idiotypic antibody was used to hyperimmunize CF1 outbred mice. As shown in Table I, mice hyperimmunized with rabbit anti-id (31-3B6) showed a $41 \%$ reduction in migrating larvae recovered from the lung when compared to mice hyperimmunized with rabbit serum $(P<0.001)$. Lung recoveries of migrating larvae was used as an initial screen since this assay has been shown to have a good correlation with adult worm recovery and can be performed in far shorter time intervals. The results of these initial studies were confirmed by measuring adult worms recovered from the mesenteric vasculature $6 \mathrm{wk}$ postinfection in additional studies utilizing identical treatment protocols. As shown in Table I, a level of $43 \%$ protection was noted.

Protection from $S$. mansoni infection varies with immunization protocol. The previous observation noted that mice hyperimmunized with antiidiotype (31-3B6) were resistant to primary infection with $S$. mansoni cercariae. Subsequent studies used varying immunization protocols, with and without adjuvant, with resistance to infection assessed by lung recoveries. Table II summarizes this series of experiments. Immunization with antiidiotypic (31-3B6) induced protection from a challenge with $S$. mansoni cercariae in all experiments tested. Most notably, antiidiotypic (31-3B6) was effective when administered without adjuvant, as a single intravenous, intraperitoneal, or subcutaneous immunization, or when as little as 75 ng IBC was used. The induction of resistance was confirmed for critical protocols by adult worm recoveries as before. These data indicate that vaccination protocols which can induce resistance to $S$. mansoni infection need not require the use of adjuvant or multiple immunizations.

Table I. Resistance to Infection with S. mansoni Cercariae of Mice Hyperimmunized with Antiidiotypic (31-3B6) or Normal Rabbit Serum (NRS)*

\begin{tabular}{cccccc}
\hline & \multicolumn{3}{c}{ Larvae } & & \multicolumn{2}{c}{ Adult worms } \\
\cline { 2 - 3 } \cline { 5 - 6 } no. & NRS & Anti-id (31-3B6) & & NRS & Anti-id (31-3B6) \\
\cline { 5 - 6 } 1 & 191 & 99 & & 32 & 42 \\
2 & 221 & 104 & & 46 & 14 \\
3 & 182 & 107 & & 42 & 18 \\
4 & 198 & 112 & & 34 & 26 \\
5 & 161 & 74 & & 46 & 34 \\
6 & 170 & 133 & & 40 & 28 \\
7 & 188 & 132 & & 46 & 16 \\
8 & 169 & 87 & & 44 & 26 \\
9 & 192 & 135 & & 50 & 14 \\
\cline { 2 - 3 } & $186 \pm 6^{\ddagger}$ & $109 \pm 7$ & & $42 \pm 2$ & $24 \pm 3$ \\
& $41 \%$ protection $P<0.001$ & $43 \%$ protection $P<0.001$
\end{tabular}

\footnotetext{
* Groups of nine mice were given four intraperitoneal injections of antiidiotype (31-3B6) emulsified in CFA or NRS every 2 wk. 4 wk later two groups of mice were challenged with $500 \mathrm{~S}$. mansoni cercariae and then migrating larvae extracted from their lungs $7 \mathrm{~d}$ later. Two other groups were challenged with $100 \mathrm{~S}$. mansoni cercariae and adult worms found in their mesenteric vasculature enumerated 6 wk postinfection.

${ }^{\ddagger}$ Data represent mean \pm SEM.
} 
Table II. Summary of Vaccine Protocols and Resultant Resistance to Infection Induced by Anti-ID (31-3B6)*

\begin{tabular}{lcccc}
\hline $\begin{array}{c}\text { Immunization } \\
\text { protocol }\end{array}$ & $\begin{array}{c}\text { Use of } \\
\text { adjuvant }\end{array}$ & Dosage (IBC) & $\begin{array}{c}\text { Number of } \\
\text { injections }\end{array}$ & Protection \\
\hline I.P. & Yes & $750 \mathrm{ng}$ & 4 & $41 \%^{\S}$ \\
SubQ and I.P. & Yes & $750 \mathrm{ng}$ & 2 & $31 \%$ \\
SubQ & No & $750 \mathrm{ng}$ & 2 & $27 \%^{\S}$ \\
SubQ & No & $750 \mathrm{ng}$ & 1 & $25 \%^{\S}$ \\
I.P. & No & $750 \mathrm{ng}$ & 1 & $24 \%$ \\
I.V. & No & $750 \mathrm{ng}$ & 1 & $28 \%$ \\
SubQ & No & $75 \mathrm{ng}$ & 1 & $16 \% \S$ \\
& & & & \\
\hline
\end{tabular}

* Groups of 8-10 mice were immunized with either antiidiotype 31-3B6 or normal rabbit serum by various protocols. All animals were then challenged 2-4 wk after the last immunization with $500 \mathrm{~S}$. mansoni cercariae and killed $7 \mathrm{~d}$ later. Percent protection was determined by counting the average number of migrating larvae found in the lungs of experimental versus control groups of mice. In all cases, protection was significant at $P<0.05$.

₹ IBC, idiotype binding capacity, a relative measure of $1 \mathrm{ml}$ of serum to binding 31-3B6 monoclonal antibody (idiotype).

${ }^{\S}$ Protection confirmed by adult worm recoveries.

Mechanism of antiidiotypic induced resistance. Animals immunized with antiidiotypic 31-3B6 vaccine were bled ten days after their final immunization but prior to challenge with $S$. mansoni cercariae. Sera were then assayed for antibody reactivity with soluble worm antigens (SWAP), a neutral salt soluble extract of $S$. mansoni adult worms which contains the 68-kD antigen bound by the monoclonal antibody $31-3 \mathrm{~B} 6$. As shown in Table III, mice hyperimmunized with antiidiotype (31-3B6) produced an antibody population that bound SWAP $\left(\mathrm{Ab}_{3}\right.$ or anti-anti-anti-antigen $)$.

Table III. Anti-worm Antibody Activity of Mice Hyperimmunized with Antiidiotype (31-3B6) or Normal Rabbit Serum*

\begin{tabular}{cccccc}
\hline & \multicolumn{2}{c}{ NRS } & & \multicolumn{2}{c}{ Anti-id (31-3B6) } \\
\cline { 2 - 3 } \cline { 5 - 6 } $\begin{array}{c}\text { Animal } \\
\text { no. }\end{array}$ & O.D. & End-titer & & O.D. & End-titer \\
\hline 1 & $0.02 \pm 0.01$ & 0 & & $0.32 \pm 0.04$ & $1 / 6,400$ \\
2 & $0.01 \pm 0.01$ & 0 & & $0.84 \pm 0.07$ & $1 / 100,000$ \\
3 & $0.02 \pm 0.01$ & $-1 / 25$ & & $0.71 \pm 0.09$ & $1 / 75,000$ \\
4 & $0.02 \pm 0.01$ & 0 & & $0.52 \pm 0.02$ & $1 / 25,000$ \\
5 & $0.03 \pm 0.01$ & 0 & & $0.41 \pm 0.01$ & $1 / 6,400$ \\
6 & $0.01 \pm 0.01$ & 0 & & $0.96 \pm 0.06$ & $1 / 100,000$ \\
7 & $0.04 \pm 0.01$ & $1 / 25$ & & $1.12 \pm 0.10$ & $1 / 400,000$ \\
8 & $0.07 \pm 0.01$ & $1 / 100$ & & $0.19 \pm 0.01$ & $1 / 6,400$ \\
9 & $0.03 \pm 0.01$ & $1 / 100$ & & $0.63 \pm 0.03$ & $1 / 25,000$ \\
10 & $0.02 \pm 0.01$ & $1 / 10$ & & $0.20 \pm 0.02$ & $1 / 10,000$
\end{tabular}

* Animals were individually bled $10 \mathrm{~d}$ after their last immunization (as outlined in Table I) but before challenge with cercariae. Serum was prepared and tested for antisoluble worm antigen antibody activity by solid-phase ELISA. Data is expressed as the mean optical density of triplicate wells at a 1/1,600 dilution or as an end-titer defined as the last dilution statistically higher than the same dilution of control serum $(P<0.05)$. In the case of the single negative titer, control serum was significantly higher than the NRS immunized animals both at a $1 / 25$ dilution.
Further studies were performed to confirm that these antiidiotype induced $\mathrm{Ab}_{3}$ antibodies portrayed similar binding characteristics as 31-3B6. As shown in Table III, serum from antiidiotype immunized mice contained $\mathrm{Ab}_{3}$ molecules that bound to SWAP by ELISA and as shown in Fig. 2, also bound to schistosomula by indirect immunofluorescence. Both of these characteristics are noted as well for 31-3B6 monoclonal antibody.

Molecular mimicry of antigen by anti-idiotype 31-3B6. Further studies were performed to detail the specificity of these $\mathrm{Ab}_{3}$ antibody molecules induced by vaccination with antiidiotype 31-3B6. Competitive inhibition studies were performed using both monoclonal antibody $31-3 \mathrm{~B} 6$ and affinity purified 31-3B6 antigen, a 68,000-D glycoprotein constituent of SWAP, as inhibitors. Initially, monoclonal antibody 31-3B6 (IgM isotype) was used to inhibit the binding of $\operatorname{IgG~} \mathrm{Ab}_{3}$ to SWAP. As shown in Table IV, inhibition of binding was noted in all of the samples tested and ranged from 3 to $32 \%$ of total $\mathrm{Ab}_{3}$ binding. The mean $\pm \mathrm{SE}$ inhibition of binding of $A b_{3}$ to antigen by monoclonal antibody $31-3 \mathrm{~B} 6$ was $13 \% \pm 6$. Such an assay would not detect IgM $\mathrm{Ab}_{3}$ molecules but this data demonstrates that a portion of the induced $\mathrm{Ab}_{3}$ antibody population and $A b_{1}(31-3 B 6)$ portray similar antigenic binding. Further studies using affinity purified 31-3B6 antigen revealed similar findings. Inhibition of binding of $A b_{3}$ to SWAP by $31-3 \mathrm{~B} 6$ antigen $(5,000 \mathrm{ng})$ ranged from 4 to $20 \%$ with a mean \pm SE value of $13 \% \pm 3$. These data indicate that a proportion of anti-schistosomal antibodies induced by immunization with antiidiotype 31-3B6 bind identical antigens as monoclonal antibody $31-3 \mathrm{~B} 6$. These data strongly suggest that antiidiotype 31-3B6 can structurally mimic $S$. mansoni antigens. It also points out that such mimicry is imperfect in that many $\mathrm{Ab}_{3}$ anti-worm antibodies produced by this immunization are not specifically inhibited by either the purified antigen or the monoclonal antibody 31-3B6.

Characterization of antiidiotype 31-3B6. Antiidiotypic antibodies can be functionally classified into three discrete subpopulations: $A b_{2} \alpha, A b_{2} \beta$, and $A b_{2} \epsilon$ (33-35). $A b_{2} \alpha$ and $A b_{2} \beta$, originally classified by Jerne et al. (34), describe the population of antiidiotypic antibodies that recognize determinants present in the variable antibody region and those that represent internal images of antigen, respectively. The $\mathrm{Ab}_{2} \beta$ antiidiotypic antibodies, therefore, have been postulated by numerous investigators to be valuable as reagents for vaccine development. The $A b_{2} \epsilon$ subpopulation is a defined (35) group of antiidiotypic antibodies that react with antigen and idiotype of an antibody directed toward the same antigen.

With regard to potential vaccine development of antiidiotypic antibodies, studies were performed to detail the presence of $\mathrm{Ab}_{2} \beta$ antiidiotypic antibodies in the polyclonal xenogeneic rabbit antiidiotype used in the present studies. Initial studies, detailing the presence of $\mathrm{Ab}_{2} \beta$ antibodies or the internal image of antigen, utilized a competitive solid-phase RIA. In the studies, the ability of rabbit polyclonal antiidiotype antibody to compete with purified antigen to bind $31-3 B 6\left(A b_{1}\right)$ antibody was determined. It was determined that only a minor proportion of rabbit antiidiotype could mimic purified antigen in binding to $A b_{1}$. As shown in Table $\mathrm{V}, 5 \mu \mathrm{g}$ of purified antigen could only inhibit at the $5 \%$ level the binding of rabbit antiidiotype to $A b_{1}$ (31-3B6 antibody). These data, therefore, indicate that only a minor subpopulation of rabbit antiidiotype could function as $\mathrm{Ab}_{2} \beta$ molecules. 

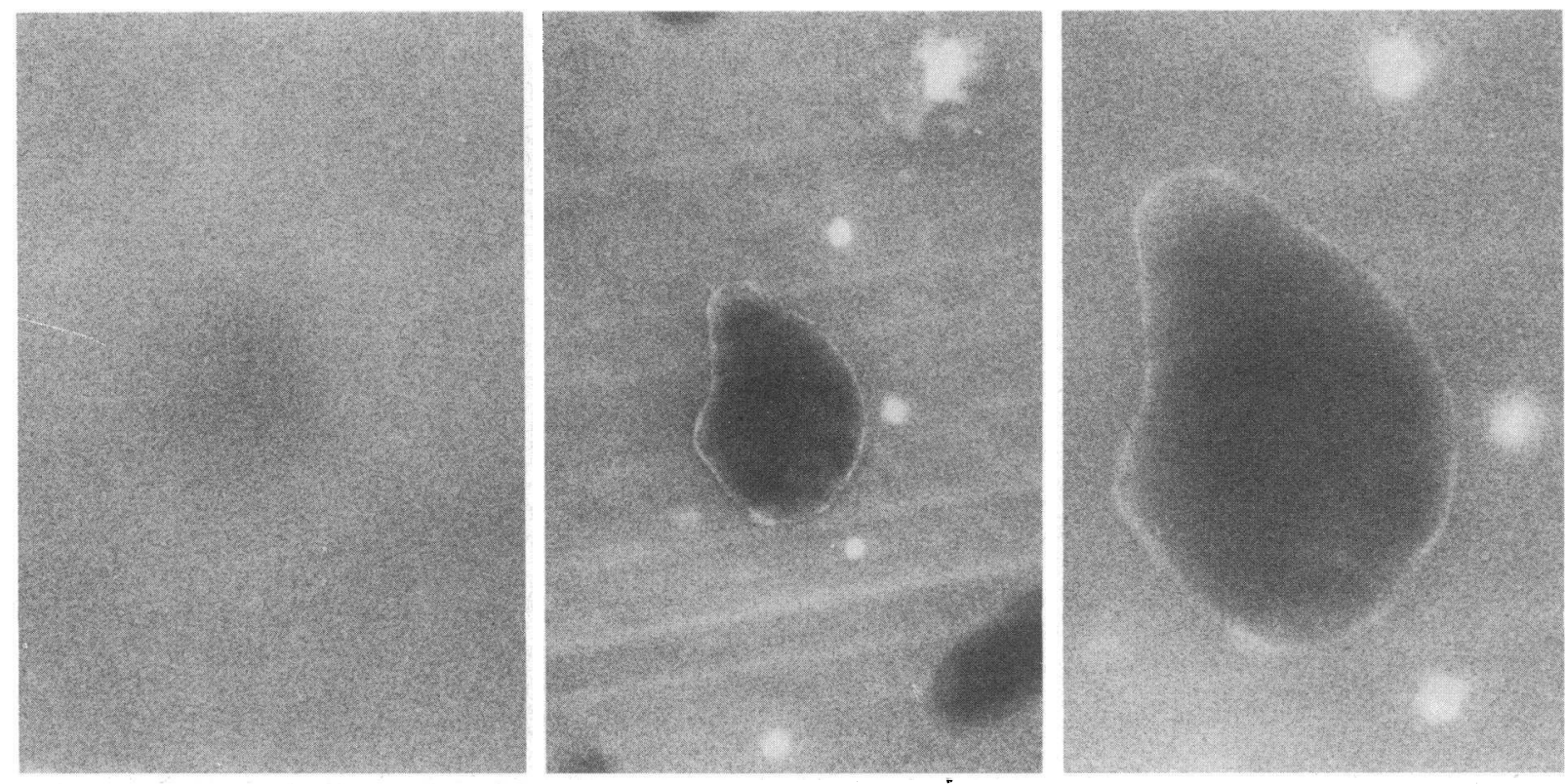

Figure 2. Immunofluorescence of 4-h, mechanically generated schistosomula. (Left) Schistosomula incubated with mouse serum from animals hyperimmunized with rabbit serum at $37^{\circ} \mathrm{C}$ for 30 min followed by staining with FITC-goat anti-mouse IgG $(\times 200)$. (Center) Schistosomula incubated with mouse serum of animals hyperimmunized with antiidiotype 31-3B6 and noted to be protected from reinfection with $S$. mansoni cercariae. These mice were noted to have anti-SWAP activity $(\times 200)$. (Right $) \times 400$ of schistosomula from center panel. Note the continuous membranous staining.

Further studies identifying the binding characteristics of polyclonal antiidiotype 31-3B6 are presented in Table VI. These data show that all animals protected from $S$. mansoni infection by antiidiotypic administration portray binding activity to absorbed polyclonal rabbit antiidiotype as determined

Table IV. Competitive Inhibition of Binding of $\mathrm{Ab}_{3}$ Antibody to Antigen (SWAP) by Murine Monoclonal Antibody 31-3B6

\begin{tabular}{cc}
\hline Animal no. & Percent inhibition \\
\hline 1 & $19 \pm 26$ \\
2 & $3 \pm 4$ \\
3 & $16 \pm 3$ \\
4 & $9 \pm 1$ \\
5 & $6 \pm 2$ \\
6 & $21 \pm 18$ \\
7 & $4 \pm 5$ \\
8 & $15 \pm 3$ \\
9 & $32 \pm 5$ \\
Mean \pm SE & $13 \pm 6$
\end{tabular}

Percent inhibition of binding of $\mathrm{Ab}_{3}$ molecules contained in serum from antiidiotype immunized mice to SWAP by 31-3B6-monoclonal antibodies. The limiting dilution of $\mathrm{Ab}_{3}$ combining serum which bound to SWAP was determined and used throughout the assay. Various concentrations of $31-3 \mathrm{~B} 6(10-5,000 \mathrm{ng})$ were then used to inhibit the binding. Binding of IgG $\mathrm{Ab}_{3}$ molecules to SWAP were detected by an IgG heavy chain specific goat antisera covalently linked to alkaline phosphatase. $31-3 \mathrm{~B} 6$ is not bound in this assay since it is a murine IgM. Data is expressed as mean percent inhibition of triplicate wells, background inhibition observed in the same dilution of control mouse serum. by ELISA. As noted earlier, however, this induced $\mathrm{Ab}_{1}$ population is apparently serologically heterogeneous. In inhibition studies, utilizing $A b_{1}$ antibodies as blocking reagents for the 31-3B6-antiidiotype interaction, a range of 5 to $12 \%$ inhibition of binding was noted by the various individual serum samples. Therefore, these studies confirm the previous findings that immunization with polyclonal antiidiotype 31-3B6 results in the establishment of an expanded antibody repertoire.

Finally, experiments were performed that would indicate the nature of the expression of the internal image of antigen of $\mathrm{Ab}_{2} \beta$ molecules. In this regard, the expression of the 31-3B6 (id-anti-id immune network) was investigated in the rat model of $S$. mansoni infection $(36,37)$. In this animal model of schistosomiasis, the Fisher rat strain developed resistance to reinfection following exposure to low numbers of cercariae (comparable to the level of infection in the present study).

Table V. Inhibition of Binding of Rabbit Anti-idiotype Antibody to 31-3B6 (Ab $\left.{ }_{1}\right)$ Antibody by Purified Antigen*

\begin{tabular}{cc}
\hline Inhibitor $^{*}$ & \% Inhibition of binding \\
\hline$n g$ & $\Sigma \pm S D$ \\
5,000 & $5 \pm 0.2$ \\
1,000 & $2 \pm 0.1$ \\
100 & $0 \pm 0.1$ \\
\hline
\end{tabular}

\footnotetext{
* Inhibition of binding of antiidiotypic antibody by purified antigen as measured by a solid-phase radioimmune assay. Varying quantities of inhibitor were added with a limiting quantity (1:5 dilution) of absorbed rabbit antiidiotype and incubated for $2 \mathrm{~h}$ in the presence of monoclonal antibody 31-3B6.

${ }^{\ddagger}$ Nanograms of affinity purified $31-3 \mathrm{~B} 6$ antigen (68 kD glycoprotein).
} 
Table VI. Generation of Ab3 Antibody Molecules Derived from Mice Resistant to Infection with $S$. mansoni Cercariae on Immunization with Rabbit Antiidiotypic Antibody*

\begin{tabular}{ccccc}
\hline & \multicolumn{5}{c}{$\begin{array}{c}\text { Optical density } \\
\text { No. of immunizations }\end{array}$} \\
\cline { 2 - 5 } Sample $^{*}$ & 1 & 2 & 3 & 4 \\
\hline 1 & 0.14 & 0.17 & 0.13 & 0.17 \\
2 & 0.30 & 0.47 & 0.42 & 0.59 \\
3 & 0.29 & 0.38 & ND & 0.42 \\
4 & 0.19 & 0.34 & 0.08 & 0.23 \\
5 & 0.15 & 0.16 & 0.23 & ND \\
6 & 0.24 & 0.32 & 0.33 & 0.37 \\
7 & 0.13 & 0.38 & 0.43 & 0.37 \\
8 & 0.14 & 0.0 & 0.17 & 0.0 \\
9 & 0.17 & 0.0 & 0.21 & 0.16 \\
& & & & \\
\hline
\end{tabular}

* Binding of Abl molecules to absorbed rabbit polyclonal antiidiotypic antibody as measured by ELISA. No O.D. readings were obtained for serum samples derived from mice administered NRS and not protected from infection (see Table I).

‡ Sample, Animal number of mice administered polyclonal antiidiotypic antibody (see Table I).

${ }^{\S}$ Serum bleed $5 \mathrm{~d}$ after injection of antiidiotypic antibodies.

Therefore, serum from Fisher rats twice infected with $S$. man soni cercariae and portraying a 50-60\% level of protection to reinfection, were utilized as inhibitors of 31-3B6-anti-idiotype binding. As shown in Table VII, a maximum level of inhibition $(86 \%)$ of rabbit antiidiotype binding to $31-3 \mathrm{~B} 6$ was noted with neat rat serum. This inhibition of binding by protective rat serum was titerable and evident even in the 1:1,000 dilution of serum tested. These data strongly indicate that rabbit polyclonal antiidiotype 31-3B6 contains $A b_{2} \beta$ based on the expression of 31-3B6 idiotypic repertoire in both rat and mouse models of $S$. mansoni infection.

Comparative protection induced by purified $31-3 B 6$ antigen versus anti-id (31-3B6) immunization. Previous studies (22) have shown that a defined $68,000-\mathrm{D}$ glycoprotein parasite antigen identified by 31-3B6 induces anti-schistosomal protection in naive mice without the use of adjuvants. In the following experiments, antiidiotypic antibody (31-3B6) was directly

Table VII. Inhibition of Idiotype-Antiidiotype Binding by Fisher Rat Serum from Infected Mice*

\begin{tabular}{lc}
\hline Serum sample & Percent inhibition \\
\hline & Mean $\pm S D$ \\
Neat & $86 \pm 0.06$ \\
$1: 10$ & $75 \pm 0.07$ \\
$1: 100$ & $66 \pm 0.03$ \\
$1: 1000$ & $62 \pm 0.05$
\end{tabular}

* Inhibition by binding of Fisher rat serum from twice infected rats of idiotype (31-3B6)-antiidiotype (31-3B6) as measured in a solidphase RIA. Inhibition levels are based on immune complex formation in the presence of normal Fisher rat serum, which averaged $7,437 \pm 1,683 \mathrm{cpm}$ performed in triplicate. compared to this purified $68-\mathrm{kD}$ antigen with regard to enhanced resistance to primary infection in vivo. As shown in Table VIII, subcutaneous immunizations with $5 \mu \mathrm{g}$ of the 68-kD antigen (previously [22] determined to be the optimal immunization protocol) induced $26 \%$ protection in vivo. Mice administered antiidiotypic antibody (two subcutaneous injections with either 750 or $75 \mathrm{ng}$ IBC) developed 26 and $17 \%$ protection, respectively $(P<0.01)$. This degree of protection was indistinguishable from that observed using purified antigen. Comparison of IBC values and purified antigen show that antiidiotype (31-3B6) can induce similar anti-schistosomal protective effects at significantly lower concentrations.

\section{Discussion}

In S. mansoni, experimental animals develop partial resistance to reinfection after a primary infection. Recent studies have suggested that an idiotype-antiidiotype immune network may be an important, naturally occurring immunoregulatory mechanism in this form of acquired resistance (38). Several investigators have tried to mimic this form of acquired resistance through the use of irradiated cercariae vaccines or artificial immunization (39-43). Purified worm antigens also have been used to stimulate resistance to primary infection in experimental animals $(22,42-44)$. These purified antigens have, in general, been identified by protective monoclonal antibodies that transfer passive resistance in vivo (22). One such monoclonal antibody was used by Grzych et al. (45) to produce a polyclonal antiidiotypic antibody that was able to induce a high level of resistance in rats in vivo. Rats, however, may not be the best model for human infection since they undergo self cure after infection and develop high levels of resistance following numerous immunologic manipulations (46). Mice, like humans, are quite susceptible to $S$. mansoni infection, sustain chronic infections, and provide a more challenging model to protect from reinfection through in vivo immunization (46). Natural infection of outbred mice, for example, results, at best, in $40 \%$ resistance to reinfection while rats develop solid immunity $(46,47)$.

Monoclonal antibody $31-3 \mathrm{~B} 6$ is an IgM that induces passive protection $(25-27 \%)$ from a challenge infection with $S$. mansoni cercariae (22). 31-3B6 binds to a $68-\mathrm{kD}$ glycoprotein contained in soluble adult worm homogenetics (SWAP) and also binds to the surface of 4-h old schistosomula as determined by indirect immunofluorescence (22). This 68-kD antigen has been found by electronmicroscopic studies to be located on the head glands of the schistosomula (unpublished observation). This monoclonal antibody (31-3B6) has also been used to purify the epitope containing $68 \mathrm{kD}$ antigen molecule by immunoabsorbant column chromatography. This purified material induces resistance (24-38\%) in mice after subcutaneous administration without adjuvant. It is not known whether the carbohydrate or protein epitopes on this molecule stimulate the protective response in vivo. To date, attempts to isolate protein epitopes of this molecule from a cDNA expression library have not been successful using either $31-3 \mathrm{~B} 6$ or a polyclonal antiserum raised in rabbits immunized with the purified $68 \mathrm{kD}$ molecule (personal communication).

Antiidiotype vaccines offer some advantages over antigen based or recombinant subunit vaccines. Antiidiotype vaccines can be effective even when the critical epitopes required for induction of resistance are carbohydrate or lipid $(16,48,49)$. 


\begin{tabular}{|c|c|c|c|c|c|}
\hline \multirow[b]{2}{*}{ Animal No. } & \multirow[b]{2}{*}{ Dose } & \multirow[b]{2}{*}{ NRS injected } & \multicolumn{2}{|c|}{ Anti-id injected } & \multirow{2}{*}{$\begin{array}{c}\begin{array}{c}\text { Antigen } \\
\text { injected }\end{array} \\
5 \mu \mathrm{g} \text { IBC }\end{array}$} \\
\hline & & & $750 \mu \mathrm{g} \mathrm{IBC}$ & $75 \mu \mathrm{g} \mathrm{IBC}$ & \\
\hline & $500 \mu \mathrm{g}$ protein & $50 \mu g$ protein & $500 \mu g$ protein & $50 \mu g$ protein & \\
\hline 1 & 133 & 124 & 128 & 133 & 91 \\
\hline 2 & 121 & 161 & 73 & 82 & 95 \\
\hline 3 & 146 & 142 & 76 & 133 & 129 \\
\hline 4 & 142 & 140 & 100 & 106 & 125 \\
\hline 5 & 136 & 129 & 120 & 108 & 70 \\
\hline 6 & 130 & 143 & & 69 & 105 \\
\hline 7 & & 146 & & 117 & 121 \\
\hline 8 & & 156 & & 159 & \\
\hline 9 & & 133 & & 138 & \\
\hline 10 & & 136 & & 134 & \\
\hline 11 & & & & 122 & \\
\hline 12 & & & & 124 & \\
\hline Mean \pm SE & $134 \pm 8$ & $148 \pm 11$ & $99 \pm 24$ & $118 \pm 24$ & $105 \pm 21$ \\
\hline$\%$ Protection & - & - & 26 & 17 & 26 \\
\hline
\end{tabular}

* Groups of mice were immunized without adjuvant subcutaneously with either the purified $68 \mathrm{kD}$ glycoprotein (identified by 31 -3B6) or with antiidiotype 31-3B6 (derived from 31-3B6 immunized rabbits). Immunization was repeated 2 wk later and then all animals challenged with 500 $S$. mansoni cercariae. Data represents migrating larvae extracted from the lungs of individual mice. Percent protection was determined by comparing antiidiotype or antigen-treated mice with NRS controls.

Antiidiotype vaccines can be mass produced at low cost, which is a major advantage over the use of antigen-based vaccines that must be extracted from an $S$. mansoni life cycle. In schistosomiasis, significant evidence exists that immune responses to worm antigens are strongly regulated by immunogenetic factors (50-52). In human schistosomiasis japonica, for example, low immune responses to worm antigens (SWAP) and development of severe clinical disease appears related to certain HLA-D-phenotypes (53). Extrapolation of these observations in $S$. mansoni would suggest the possibility that antigenbased vaccines, even those produced through recombinant technology may not induce a protective response in the subset or individuals who most need enhanced resistance to reinfection. To this point, antiidiotype vaccines are advantageous since antiidiotype manipulation is capable of overcoming such immunogenetic barriers $(8,54,55)$. Finally, antiidiotype vaccines are quite potent and provide a reasonable alternative to other vaccine strategies. In the Sendai virus model, for example, antiidiotype manipulation is even more effective than a natural infection in inducing protective responses in vivo (56).

The requirements of the induction of a protective antiidiotype-induced immune response to murine reovirus infection have been reported (57). High titer of neutralizing antibody was noted using a chronic immunization protocol that utilized a regimen of complete and incomplete Freund's adjuvant or alum. An additional requirement was the cross-linking or covalent coupling of monoclonal antiidiotypic antibody to a carrier molecule (57). These stringent requirements were not necessary, however, to produce anti-viral $\mathrm{T}$ cell immunity in mice (26). In addition, as recently reviewed by Hiernaux (58), numerous experimental systems of infectious diseases have utilized antiidiotypic antibody without the use of adjuvant to induce protective immunity. As in the presently reported study, these volumes of data infer that various forms of immunity to infectious agents can be generated by using antiidiotype antibodies. However, the requirements for the type of protective immunity generated and level of protection depend on the individual experimental system.

In the present study, xenogeneic antiidiotypic antibody was used to induce varying levels of protection to a challenge with $S$. mansoni cercariae in outbred mice. Levels of protection ranged from 16 to $41 \%$ depending on the immunization protocol. Antiidiotype, however, remained effective even when given as a single intravenous, subcutaneous, or intraperitoneal injection without adjuvant. Although this degree of resistance $(16-43 \%)$ is modest compared to vaccines for other infectious diseases, it is important to note that helminths do not multiply in the definitive host and, therefore, anti-worm vaccines can have a significant impact on disease even if only partially effective (59).

This level of resistance compares favorably to that observed in mice after the passive transfer of serum from $S$. mansoni infected animals (46), following adjuvant therapy (60), following immunization with irradiated cercariae vaccines (39-41), or immunization with purified antigens generally administered with complete Freund's or other adjuvant $(61,62)$.

This study details the direct comparison of purified antigen (68 kD glycoprotein) immunization with antiidiotype induced resistance. Antiidiotype immunization was equally effective in inducing resistance in vivo and required significantly less material (5 $\mu \mathrm{g}$ of purified antigen compared to $750 \mathrm{ng}$ idiotype binding capacity).

The mechanism by which xenogeneic antiidiotype immunization induced resistance in vivo was explored by characterizing the immune response of immunized mice before their 
challenge with $S$. mansoni cercariae. Antiidiotype immunized mice developed significant antibody titers, $\mathrm{Ab}_{3}$ molecules, which reacted against worm antigens before their exposure to the parasite. These antibodies $\left(\mathrm{Ab}_{3}\right)$ also bound to living schistosomula, the presumed target of immune attack. In addition, $\mathrm{Ab}_{3}$ binding to antigen (SWAP) could be inhibited by either monoclonal 31-3B6 $\left(\mathrm{Ab}_{1}\right)$ or affinity purified antigen in a dose-dependent manner. These observations strongly suggest that the antiidiotype 31-3B6 immunization produced an $\mathrm{Ab}_{3}$ antibody response that portrayed $A b_{1}$ (31-3B6-like) activity. This antigen's mimicry quality of certain antiidiotypes has been suggested as the basis for other protective antiidiotype vaccines (8). Mimicry was not, however, perfect in that antiidiotype vaccination resulted in $\mathrm{Ab}_{3}$ molecules that bound worm antigens but were not inhibited by either $31-3 \mathrm{~B} 6$ or the 68-kD antigen. However, the present study, which does not detail the fine specificity of the $\mathrm{Ab}_{3}$ population, does not rule out the possibility of antibody affinity differences and cross-reactivity among the various antibody substrates.

Nevertheless, the present observations raise the possibility that antiidiotype immunization may stimulate the production of a broader immune response than purified antigen itself. The potential role of these $A b_{3}$ immunoglobulins, which may not strictly involve the 68-kD-31-3B6 immune network in the induction of resistance to Schistosoma mansoni, is presently under investigation.

Conclusion. An antiidiotype-based vaccine is a viable alternative to purified antigen-based vaccines or recombinant subunit vaccines particularly if the protective epitopes are carbohydrate in nature. Antiidiotype vaccines are effective in experimental schistosomiasis when given without adjuvants and even after a single immunization. Antiidiotype administration induced an $\mathrm{Ab}_{3}$ response that identifies the epitope-containing molecule which initiates the immune network and suggests that at least part of the mechanism of induced resistance by antiidiotype is through its molecular mimicry of antigen.

\section{Acknowledgments}

The authors thank Ms. Candace Finegan, Ms. Lori Aruscavage, and Ms. Cynthia Jamison for their technical assistance, and Ms. Tammy Lederer for typing this manuscript.

Supported by National Institutes of Health grants, AI-21080-02 and AI-25167-01, and grants from the Edna McConnell Clark Foundation and the Rockefeller Foundation.

\section{References}

1. Jerne, N. K. 1974. Toward a network theory of the immune response. Ann. Immunol. (Paris). 125C:373-387.

2. Rodkey, L. S. 1980 . Autoregulation of immune response via idiotype network interactions. Microbiol. Rev. 44:631-659.

3. Urbain, J., C. Wailmart, and P. A. Cazenave. 1981. Idiotype regulation in immune networks. Cont. Top. Mol. Immunol. 8:113148.

4. Kelsoe, G., M. Reth, and K. Rajewsky. 1980. Control of idiotype expression of monoclonal anti-idiotypic antibodies. Immunol. Rev. 52:75-96.

5. Roitt, I. M., Y. M. Thanavala, D. K. Male, and F. C. Hay. 1985. Anti-idiotypes as surrogate antigens: structural considerations. Immunol. Today 6:265-267.

6. Kohler, H., S. Muller, and C. Bona. 1985. Internal antigen and immune network. Proc. Soc. Exp. Biol. Med. 178:189-195.
7. Bruck, C., M. S. Co, M. Slgoui, G. N. Gaulton, T. Smith, B. N. Fields, J. I. Mullins, and M. I. Greene. 1986. Nucleic acid sequence of an internal image-bearing monoclonal anti-idiotype and its comparison to the sequence of the external antigen. Proc. Natl. Acad. Sci. USA. 83:6578-6582.

8. Nisonoff, A., and E. Lamoyi. 1981. Implication of the presence of an internal image of the antigen in anti-idiotypic antibodies. Possible applications to vaccine production. Clin. Immunol. Immunopathol. 21:397-406.

9. Sacks, D. L., G. H. Kelsoe, and D. Sachs. 1983. Induction of immune responses with anti-idiotypic antibodies: implications for the induction of protective immunity. Springer Semin. Immunopathol. 6:79-97.

10. Hay, F. C., Y. Thanavala, and I. M. Roitt. 1984. In Immunizations Intervention I: New Ideas in Vaccines. Academic Press, Inc., Orlando, FL. 1-17.

11. Kohler, H., and C. Bona. 1986. Idiotype Vaccines. In International Review of Immunology. Vol. 1. Haewood Press, New York. $1-90$.

12. Keiber-Emmons, T., R. E. Ward, S. Raychaudhuri, R. Rein, and H. Kohler. 1986. Rational design and application of idiotype vaccines. Int. Rev. Immunol. 1:1-26.

13. Kennedy, R. C., J. E. Eichberg, R. E. Landford, and G. R. Dreesman. 1986. Anti-idiotypic vaccine for type $B$ viral hepatitis in chimpanzees. Science (Wash. DC). 232:220-223.

14. Sacks, D. L., K. M. Esser, and A. Sher. 1982. Immunization of mice against African trypanosomiasis using anti-idiotypic antibodies. J. Exp. Med. 155:1108-1119.

15. Sacks, D. L., and A. Sher. 1983. Evidence that anti-idiotype induces immunity to experimental African trypanosomiasis is genetically restricted and requires recognition of combining site-related idiotypes. J. Immunol. 131:1511-1515.

16. McNamara, M. K., R. E. Ward, and H. Kohler. 1984. Monoclonal idiotope vaccine against streptococcus pneumonia infection. Science (Wash. DC). 226:1325-1326.

17. Stein, K. E., and T. Soderstrom. 1984. Neonatal administration of idiotype or anti-idiotype primes for protection against Escherichia coli K13 infection in mice. J. Exp. Med. 160:1001-1011.

18. Kennedy, R. C., and G. R. Dreesman. 1984. Enhancement of the immune response to hepatitis $B$ surface antigen. In vivo administration of anti-idiotype induces anti-HBs that expresses a similar idiotype. J. Exp. Med. 159:655-665.

19. Ertl, H. C. J., and R. W. Finberg. 1984. Sendai virus-specific T-cell clones: Induction of cytolytic $T$ cells by an anti-idiotypic antibody directed against a helper T-cell clone. Proc. Natl. Acad. Sci. USA. 81:2850-2854.

20. Sharp, A. H., G. N. Gaulton, K. M. McDade, B. N. Fields, and M. I. Greene. 1984. Syngeneic monoclonal anti-idiotype can induce cellular immunity to reovirus. J. Exp. Med. 160:1195-1205.

21. Uytedehaag, F. G. C. M., and A. D. M. E. Osterhaus. 1985. Induction of neutralizing antibody in mice against polio virus Type II with monoclonal anti-idiotypic antibody. J. Immunol. 134:12251229.

22. King, C. H., R. R. Lett, J. Nanduri, S. El Ibiary, P. A. S. Peters, G. R. Olds, and A. A. F. Mahmoud. 1987. Isolation and characterization of a protective antigen for adjuvant-free immunization against Schistosoma mansoni. J. Immunol. 139:4218-4224.

23. Kuettner, M. G., A. L. Wang, and A. Nisonoff. 1972. Quantitative investigations of idiotypic antibodies. I. Idiotypic specificity as a potential genetic marker for the variable regions of mouse immunoglobulin polypeptide chains. J. Exp. Med. 135:579-589.

24. Olds, G. R., and T. F. Kresina. 1985. Network interaction in Schistosoma japonicum infection. Identification and characterization of a serologically distinct immunoregulatory auto-anti-idiotypic antibody population. J. Clin. Invest. 76:2338-2347.

25. McConalley, J., and F. J. Dixon. 1966. A method of trace iodination of proteins for immunologic studies. Int. Arch. Allergy 29:185-198. 
26. Lowry, G. H., N. J. Rosebrough, A. L. Farr, and R. J. Randall. 1951. Protein measurement with the Folin phenol agent. J. Biol. Chem. 193:154-165.

27. Smithers, S. R., and R. J. Terny. 1965. The infection of laboratory hosts with cercariae of Schistosoma mansoni and the recovery of adult worms. Parasitology. 55:695.

28. Sher, A., P. MacKenzie, and S. R. Smithers. 1974. Decreased recovery of invading parasites from the lungs as parameter of acquired immunity to schistosomiasis in the mouse. J. Infect. Dis. 130:626.

29. Daniel, T. M., and G. R. Olds. 1985. Demonstration of a shared epitope among mycobacterial antigens using a monoclonal antibody. Clin. Exp. Immunol. 60:249-258.

30. Colley, D. G., J. A. Cook, G. L. Freeman, R. K. Bartholomew, and $P$. Jordan. 1977. Immune responses during human schistosomiasis mansoni. I. In vitro lymphocyte blastogenic responses to heterogeneous antigenic preparations from schistosome eggs, worms and cercariae. Int. Arch. Allergy Appl. Immunol. 53:420.

31. Ramalho-Pinto, F. J., G. Gazzinelli, R. E. Howells, T. A. Mota-Santos, E. A. Figuierido, and J. Pelligrino. 1974. Schistosoma mansoni: defined systems for stepwise transformation of cercariae to schistosomula in vitro. Exp. Parasitol. 36:360.

32. Zodda, D. M., and S. M. Phillips. 1982. Monoclonal antibodymediated protection against Schistosoma mansoni infection in mice. $J$. Immunol. 129:2326-2332.

33. Bona, C. 1988. Anti-idiotypes. In Biological Applications of Anti-Idiotypes. C. A. Bona, editor. Volume 1. CRC Press, Boca Raton, FL. 1-12.

34. Jerne, N. K., J. Roland, P. A. Cazenave. 1982. Recurrent idiotopes and internal images. EMBO (Eur. Mol. Biol. Organ) J. 1:243257.

35. Bona, C. A., S. Finley, S. Water, and H. G. Kunkel. 1982. Anti immunoglobulin antibodies. III. Properties of sequential anti-idiotypic antibodies to heterologous anti- $\lambda$ globulins. Detection of reactivity of anti-idiotype antibodies with epitopes of $\mathrm{Fc}$ fragments (homobodies) and with epitopes and idiotypes (epibodies). J. Exp. Med. 156:986993.

36. Knopf, P. M., T. B. Nutman, and J. A. Reasoner. 1977. Schistosoma mansoni: resistance to reinfection in the rat. J. Parasitol. 41:74-81.

37. Phillips, S. M., and W. A. Reid. 1980. Schistosoma mansoni: immune responses to normal and irradiated cercariae or soluble stagespecific surface immunogens. Int. J. Nucl. Med. Biol. 7:173-179.

38. Phillips, S. M., E. G. Fox, N. J. Fathelbab, and D. Walter. 1986. Epitope and paratopically directed anti-idiotypic factors in the regulation of resistance to murine schistosomiasis mansoni. J. Immunol. 137:2339-2347.

39. Capron, A., J. P. Dessaint, M. Capron, J. H. Ouma, and A. E. Butterworth. 1987. Immunity to schistosomes: progress toward vaccine. Science (Wash. DC). 238:1065-1072.

40. Sher, A., S. Hiery, S. L. James, and R. Asofsy. 1982. Mechanisms of protective immunity against Schistosoma mansoni infection and mice vaccinated with irradiated cercariae. II. Analysis of immunity in hosts deficient in T lymphocytes, B lymphocytes, or complement. J. Immunol. 128:1188-1888.

41. Bickle, Q. D., B. J. Andrews, M. J. Dienhoff, M. J. Fund, and M. G. Taylor. 1985. Resistance against Schistosoma mansoni induced by highly irradiated infections: studies on species specificity of immunization and attempts to transfer resistance. Parasitology. 90:301-312.

42. Pearce, E. J., S. L. James, J. Dalton, A. Barrall, C. Ramos, M. Strand, and A. Sher. 1986. Immunochemical characterization and purification of SM-97, a Schistosoma mansoni antigen monospecifically recognized by antibodies from mice protectively immunized with a nonliving vaccine. J. Immunol. 137:3593-3597.
43. Balloul, J. M., J. M. Grzych, R. J. Pierce, and A. Capron. 1987. A purified 28,000 dalton protein from Schistosoma mansoni adult worms protects rats and mice against experimental schistosomiasis. $J$. Immunol. 138:3448-3453.

44. Lanar, D. E., E. J. Pearce, S. L. James, and A. Sher. 1986. Identification of paramyosin as schistosome antigen recognized by intradermally vaccinated mice. Science (Wash. DC). 234:593-596.

45. Grzych, J. M., M. Capron, P. H. Lambert, C. Dissovs, S. Torres, and A. Capron. 1985. An anti-idiotype vaccine against experimental schistosomiasis. Nature (Lond.). 316:74-76.

46. Dean, D. A. 1983. A review of schistosoma and related genera: Acquired resistance in mice. Exp. Parasitol. 5:1-104.

47. Capron, M., and A. Capron. 1986. Rats, mice and menModels for immune effector mechanisms against schistosomiasis. Parasitology Today. 2:70-75.

48. Reagan, K. J., W. H. Wunner, T. J. Wikton, and H. Koprowski. 1983. Anti-idiotypic antibodies induce neutralizing antibodies to rabies virus glycoprotein. J. Virol. 48:660-666.

49. Olds, G. R. 1988. Immunopathology and resistance in helminth infections. In Parasitic Infections. M. A. Sande, J. H. Leech, and R. K. Root, editors. Churchill Livingstone, Inc., New York. In press.

50. Salam, E. A., S. Ishaac, and A. A. F. Mahmoud. 1978. Histocompatability-linked susceptibility of hepatomegaly in human schistosomiasis mansoni. J. Immunol. 26:195-254.

51. Abdel-Salam, E., A. Kalik, A. Meguid, W. Barakat, and A. A. F. Mahmoud. 1986. Association of HLA Class I antigens (AL, B5 and CW2) with disease manifestations and infection in human schistosomiasis mansoni in Egypt. Tissue Antigens. 27:142-146.

52. Sasazuki, T., W. Ohta, R. Kaneoka, and S. Kojima. 1980. Association between an HLA haplotype and low responsiveness to schistosomal worm antigen in man. J. Exp. Med. 152:3145-3185.

53. Ohta, N., Y. K. Nishimora, M. T. Iuchi, and T. Sasazuki. 1982. Immunogenetic analysis of patients with post-schistosomal liver cirrhosis in man. Clin. Exp. Immunol. 49:493-499.

54. Marriott, S. J., D. J. Roeder, and R. A. Consigli. 1987. Antiidiotypic antibodies to a polyomavirus monoclonal antibody recognize cell surface components of mouse kidney cells and prevent polyomavirus infection. J. Virol. 61:2747-2753, 1987.

55. Dreesman, G. R., and R. C. Kennedy. 1985. Anti-idiotypic antibodies: Implications of internal image-based vaccines for infectious diseases. J. Infect. Dis. 151:961-965.

56. Ertl, H. C. J., E. Homans, S. Tournas, and R. W. Finberg. 1984. Sendi virus-specific $T$ cell clones $V$. Induction of cytolytic $T$ cells by an anti-idiotypic antibody directed against a helper T cell clone. J. Exp. Med. 159:1778-1783.

57. Gaulton, G. N., A. H. Sharpe, D. W. Chang, B. N. Fields, and M. I. Greene. 1986. Syngeneic monoclonal internal image anti-idiotypes as prophylactic vaccines. J. Immunol. 137:2930-2936.

58. Hiernaux, J. 1988. Idiotype vaccines and infectious diseases. Infect. Immun. 56:1407-1413.

59. Warren, K. S. 1981. The control of helminths: Non-replicating infectious agents of man. Annu. Rev. Public Health 2:101-138.

60. Mahmoud, A. A. F. 1982. Nonspecific resistance to parasitic infection. In Immunology of Parasitic Infections. S. Cohen and K. S. Warren, editors. Blackwell Scientific, London, England. 99-115.

61. Smith, M. A., and J. A. Clegg. 1985. Vaccination against schistosoma mansoni with purified surface antigens. Science (Wash. DC). 277:535-537.

62. Sher, A., E. J. Pearce, S. Hienj, and S. L. James. 1986. Induction of protective immunity against Schistosoma mansoni by a non-living vaccine. IV. Fractionation and antigenic properties of a soluble adult worm immunoprophylactic activity. J. Immunol. 136: 3878-3883. 